\title{
THE PRODUCTION OF IRREGULAR MIGRANTS: THE CASE OF NORWAY
}

\author{
Synnøve BENDIXSEN'
}

COBISS 1.01

\begin{abstract}
The Production of Irregular Migrants: The Case of Norway

Irregular migration is a growing phenomenon in Europe and elsewhere. In Norway, as in other European countries, there has been a process of heavy restrictions and limited liberalisation in asylum and immigration policies. Drawing on research on irregular migration and my own fieldwork with irregular migrants in Norway, this article discusses four areas of government action that explain how irregular migration is produced, namely 1) the de- and reestablishing of borders, 2) categorization as a management strategy, 3) the production of a deportable subject and, finally, 4) the criminalization of people who are in the territory "illegally". These are complexly interrelated techniques used by governments in their efforts to exercise authority over people who are in the nation-state "illegally". I focus on how the nation-state configures and produces irregular migrants in their own back yard. The governmentality of irregular migrants is simultaneously the production of such a category of people.
\end{abstract}

KEY WORDS: irregular migration, governmentality, social borders, deportation, criminalization

\section{IZVLEČEK}

Ustvarjanje nedokumentiranih migrantov: primer Norveške

Nedokumentirane migracije so $v$ porastu tako v Evropi kot drugje po svetu. Na Norveškem, kot tudi v preostalih evropskih državah, zaznavajo zastoj liberalizacije azilnih in migracijskih politik in porast restriktivnih ukrepov. Članek temelji na raziskavi nedokumentiranih migracij in avtoričinem terenskem delu z nedokumentiranimi migranti na Norveškem ter ponuja analizo štirih področij vladnih ukrepov. Ti pojasnjujejo način ustvarjanja nedokumentiranosti: 1) odstranitev in ponovna vzpostavitev meja; 2) kategorizacija kot strategija upravljanja; 3) ustvarjanje kategorije subjekta za deportacijo; in 4) kriminalizacija "nezakonito« priseljenih ljudi. Namen kompleksno prepletenih vladnih tehnik je upravljati $\mathrm{z}$ »nezakonito« priseljenimi ljudmi. Članek se osredotoča na načine konfiguracije in ustvarjanja nedokumentiranih migrantov na ozemlju nacionalne države, saj prav vladnost nedokumentiranih migracij hkrati ustvarja tovrstno kategorizacijo ljudi.

KLJUČNE BESEDE: nedokumentirane migracije, vladnost, družbene meje, deportacija, kriminalizacija

$\mathrm{PhD}$ in Social Anthropology; University of Bergen, Institute of Social Anthropology, 78005020 Bergen, Norway; Synnove.bendixsen@uib.no 


\section{INTRODUCTION}

Irregular migration is a growing phenomenon in Europe and elsewhere. One reason for this is that it has become difficult to migrate within the framework set by national and supranational bodies, and prior authorizations for international mobility are increasingly required. In Norway, as in other European countries, there has been a process of heavy restrictions and limited liberalisation in asylum and immigration policies. On the one hand, labour markets have been opened to EU nationals and a limited number of highly skilled migrants - moving policy in a more liberal direction (Spencer 2003). On the other hand, border controls have been intensified and technologized in order to limit unauthorised entrance, and asylum seekers' right to work has been largely withdrawn. The application of liberal principles to the migration of desired groups of migrants, and illiberal forms of governing through an increase in control measures applied to undesired groups of migrants, illustrates how states combine liberal forms of governance with disciplinary forms, or policing (Walters 2002).

Drawing on the increasingly expanding research on irregular migration and fieldwork with irregular migrants in Norway in the period 2011-2013, this article discusses the various ways irregular migration is governed and constructed as a particular form of problem and political concern in Norway. I here use governmentality as developed by Foucault $(1991,2002)$ as an analytical approach in order to "denaturalize features that have become second nature" (Walters 2012: 14). In a broad sense, governmentality means "the conduct of conducts", and the focus is on the practices, techniques and rationalities that are intended to shape actions in order to achieve specific goals. Frequently, the aim of a governmentality analysis is to examine the way the government attempts to shape human action: "To analyse government is to analyse those practices that try to shape, sculpt, mobilize and work through the choices, desires, aspirations, needs, wants and lifestyles of individuals and groups" (Dean 2010: 20). It importantly provides a framework to unpack relational politics and ethics, by drawing our gaze towards the connections between governments, politics and authority and the identity and the self (Dean 2010: 20).

In this article I will distinguish four fields of government actions that explain how irregular migration is produced, namely 1) the de- and reestablishing of borders, 2) categorization as a management strategy, 3) the production of a deportable subject and, finally, 4) the criminalization of people who are in the territory 'illegally'. These are complexly interrelated techniques used by governments in their efforts to exercise authority over people who are in the nation-state 'illegally'. I focus on how the nation-state configures and simultaneously produces irregular migrants in their own back yard.

While the focus in this article is on how the state constructs illegality, it still recognizes migrants as active subjects, e.g. the migrant becomes 'illegal' through crossing borders without the proper authorization, or has not left the nation-state after the rejection of their asylum application and the date of exit. However, in this article I will focus on how irregular migration is produced not through a migrant's act, but rather through the various forms through which irregularity is produced. As the French philosopher Ėtienne Balibar (2000: 42) argues in his discussion of the political mobilization of irregular migrants in France:

The sans-papiers have shown that their illegality has not been reformed by the state but rather created by it. They have shown that such a production of illegality, destined for political manipulation, 
could not be accomplished without constant attacks on civil rights (in particular, personal safety, which proceeds from the non-retroactivity of laws to the respect of dignity and physical integrity) nor without constant compromises with neo-fascism and the men who promote it.

Finally, the aim of the article is to also draw attention to some of the pitfalls we face as researchers in this methodologically challenging, but increasingly important, field of study. Migration in general and irregular migration in particular is a highly politicized field. Knowledge of irregular migration is sought after by governments, politicians, police and NGOs who wish to advance specific agendas relating to migration control, welfare rights, and questions of exclusion/inclusion. Research is often used to legitimize various political positions in a polarized debate. Extra caution is necessary with regard to how research questions are composed and pursued and how results are presented.

\section{THE DESTABILIZING AND REESTABLISHING OF BORDERS}

Without borders there would be no irregular migration. At the beginning of the 1990s, influential voices spoke of a "borderless world" and celebrated what seemed to be a de-bordering of the state due to globalization processes. However, while scholars tended to argue that the nation-state had lost control, of which the lack of capacity to control unwanted migration was evidence (e.g. Soysal 1996, Sassen 1996), today scholars are increasingly recognizing that governments' migration control mechanisms have not declined, but in fact changed (Guiraudon, Lahav 2000). Few disagree that the relevance of territoriality has shifted rather than weakened (Andreas 2000). Governments have shifted the level at which policy is expanded and executed. For example, national governments have devised a number of ways to circumvent normative constraints deriving from international jurisprudence. As Guiraudon and Lahav (2000: 164) have showed, decision making has shifted "upward to intergovernmental fora, downward to elected local authorities, and outward to private actors such as airline carriers, shipping companies, employers, and private security agencies." The consequent multifaceted and decentralization of migration policy does not mean that states have lost control over migration, but rather illustrates the capacity for adaptation and adjustments in the state apparatus and agencies in charge of migration: "By sharing competence, states may have ceded exclusive autonomy yet they have done so to meet national policy goals, regaining sovereignty in another sense: capabilities to rule" (Guiraudon, Lahav 2000: 164).

Borders are as important as ever; Balibar (2002: 84-85) refers to the continuous changing of their forms, structures and techniques as the "ubiquity of borders". Today borders are constructed, reproduced and contested by a variety of actors, using techniques, institutions, laws, policies and social interactions at different scales (Bendixsen 2016). At the same time, the border is both a temporal and spatial experience. The effect of the border on migration, regular and irregular, is experienced differently depending on one's legal status, country of origin, ethnicity, race, gender, age, etc. (Balibar 2002; Yuval-Davis 2004; Rumford 2006; Nyer 2010; Fassin 2011). Borders have the ability "to appear or disappear, to materialize at certain times or for certain groups of people with sudden intensity; to morph, or acquire the quality of permanent fixture" (Reeves 2014: 7). Time and temporality play important parts in border management (Nyer 2010): for some, the border can 
mean impediments, delays, and increased waiting times, while for others it signifies swift movement and speedy processing as a "trusted" traveller (Nyer 2010). As Balibar puts it, "borders are polysemic" (2002: 82), in that "borders never exist in the same way for individuals belonging to different social groups" (2002: 78-79).

This multiplication of borders also produces irregular migration in its various forms. The implementation of European integration, for instance through the Schengen Agreement, has made it increasingly difficult for undocumented travellers such as asylum seekers to cross the external Schengen borders. Immigration laws formulate restrictions on the entry and stay of aliens in a nation-state, and as such define what is legal. Simultaneously, immigration laws generate an area of what are considered to be illegal practices. De Genova (2002: 430) asserts that:

Illegality" is the product of immigration laws - not merely in the abstract sense that without the law, nothing could be construed to be outside of the law; nor simply in the generic sense that immigration law constructs, differentiates, and ranks various categories of "aliens" - but in the more profound sense that the history of deliberate interventions that have revised and reformulated the law has entailed an active process of inclusion through "illegalization".

The distinction between physical border and social boundaries is relevant here: while borders are "external territorial frontiers", boundaries are internal social categorizations which "are tightly related in a process in which immigrants are racialized and ethnic minorities are reminded of their foreign origin" (Fassin 2011: 214). These forces work concurrently and contain processes of "migrant illegality" (de Genova 2002) and "immigrant racialization" (Silverstein 2005).

Internal borders or social boundaries within the nation-states increasingly regulate who can access certain social and health rights. In Norway, social boundaries have come to include welfare-state regulations concerning who has what rights. The Nordic welfare states are characterized by an extensive welfare-state model, where citizens' welfare is significantly addressed through programs and institutions that are mainly publicly funded through taxation. The right to welfare services is mainly based on citizenship and residency, rather than employment, income or past contributions to the welfare system. Equality and inclusion of citizens is a major ambition. Among the Nordic countries, the welfare system has played a significant role for the inclusion of migrants and refugees across the ideological and political differences (Olwig 2010; Rugkåsa 2012). When it comes to irregular migrants, these countries are, however, on the restrictive side, in terms of both formal and informal enrolment in welfare programs.

The last decade's increase in internal social boundaries within the nation states through welfare laws, regulations and practices facilitate, obstruct and set yardsticks for migrants' entrance into society (Bendixsen 2016). Recent discussions have concerned the extent of healthcare to be provided to irregular migrants. Norwegian welfare law defines the scope of the law as 'everyone residing in the realm', without any mention of legality (Søvig 2013). Consequently, for some time there was uncertainty concerning whether irregular migrants were entitled to certain services. However, in the past decade there has been a discussion concerning who should be included in 'everyone'. While irregular migrants are still included in a few cases (i.e. the Child Welfare Act (1992), the Education Act (1998) and the Act on Crisis Shelters (2009)), irregular migrants' access to services has been increasingly 
circumvented by various regulations and circulars issued by government departments that redefine the scope of the law to mean only "legal residents" (Søvig 2013). One outcome of a review of existing laws initiated by the Norwegian Ministry of Health due to what they called 'continuing doubt and varying practices', was a new healthcare regulation (which entered into force in July 2011) which restricted irregular migrants' access to healthcare to include only emergency care and healthcare that cannot be delayed "without danger of imminent death, permanent and seriously reduced functionality, serious injury, or severe pain" (Healthcare Regulation 2011). ${ }^{1}$

Interpretations of rights and rules are produced and acted upon when irregular migrants encounter welfare institutions and welfare workers, such as when an irregular migrant visits an Emergency Care unit. During my fieldwork I observed that on occasion an irregular migrant would borrow someone else's identity papers and thus face no difficulties in receiving medical attention. Other times, the migrant was rejected by the receptionist because he or she was not a legal resident in Norway. Yet other times, the migrant would not even try to obtain health care because they lacked valid papers, did not have the money to pay the bill or feared that the receptionist or doctor would call the police. ${ }^{2}$ While health care providers in Germany have a certain duty to report irregular migrants, this is not the case in Norway. Still, I met migrants who feared they would be reported, which could lead to their deportation. Face-to-face meetings between irregular migrants and welfare workers are shaped by both the various actors' knowledge and values, and by representations of irregular migration circulating in the media and in public debate (Bendixsen 2015). Irregular migrants' interactions with the nation-state in which they are living can consequently be characterised as being "simultaneously inside and outside", "on the margin", or that they are in a space where there is "no way out, no way in" (Sigona, Hughes 2012).

While the private sector (including family, friends, and NGOs) is crucial to welfare provisions in many societies, in the Nordic countries the nation-state regulates substantial parts of residents' welfare and social life. As a consequence, relations between individuals, organizations, and the nation-state are fundamental (Esping Andersen 1990). The close relations between individuals, organizations and the nation-state - also called "strong welfare states" - in Scandinavia make it harder for those who are excluded from public arrangements to get by (Khosravi 2010). It appears as if the welfare state borders must be carefully regulated and guarded precisely because the welfare system is so generous. The Nordic welfare model is thus in many ways, both formally and informally, exclusionary towards irregular migrants, and comes to take the character of "welfare chauvinism" (Andersen, Bjørklund 1990).

In sum, accountability and control mechanisms for migration have moved inwards towards the societal level: nation-states have shifted their focus from territorial border marking to a politics of social boundary production and assertion within the nation-state, where actors such as welfare and health providers become de facto border control managers (Bendixsen 2016). Another way in which the nation-state produces irregular migration is through its effort to count and categorize, to which I now turn.

1 Children, pregnant women, prisoners and persons with communicable diseases are granted some additional rights.

2 In Oslo there is a health care unit set up by NGOs particularly for irregular migrants. Many irregular migrants make use of this health care service. 


\section{THE POLITICS OF NUMBERS AND CATEGORIZATION}

In Norway the government operated until recently with a guesstimate from Statistics Norway (Zhang 2008) which estimated that the number of people without legal residence in 2006 ranged between 10,000 and 32,000. Of these, 12,325 had previously applied for asylum (Zhang 2008). This category includes people who have sought asylum but have been rejected and not left Norway; people who stayed in the country after their visa expired; and people who came into the country without legal authorization. ${ }^{3}$ In Norway, and more generally in Europe, there is a tendency that the higher estimate is referred to as the real number, which has become a myth-buster. Among these is a predominance of single men, but also women and families. The ethnic and national background are similar to those who apply for asylum, and who have relatively high rejection rates, namely people from Afghanistan, Iraq, Ethiopia, Palestine, Somalia, and Sri Lanka.

Zhang (2008) called his estimate a "guesstimate" in order to indicate the practical difficulties of establishing reliable statistics in this field. This number has become political; some emphasize the low number, partly to argue that irregular migrants is a group that does not represent a major problem and thus the government should provide them with assistance. Others, such as politicians on the right, emphasize the elevated number in order to illustrate that irregular migration is a government and police problem which needs increased focus and security endorsements, and linking the group to criminality issues. This latter approach has been defined as "crime migration" - the connection of two governmental areas (migration policies and crime) that used to be separate but which have become increasingly complexly integrated - to which I will return below.

Providing an account of irregular migrants is not only about providing an overview of the population as part of the governmental management and control of who is living on the territory (cf. Foucault 2002). The estimated numbers and construction of categories of irregular migrants simultaneously become part of the underpinning of how irregular migration is viewed as a problem, and what kind of problem irregular migration is constructed to be: for some actors it becomes an issue of humanitarian concern, for others it is presented as a "security problem". Statistics are crucial to modern forms of government (Foucault 2002). In the case of irregular migrants, statistics serve not only to acquire knowledge about the population, but also to identify those considered as illegitimate part of the nation-state's population and must therefore be excluded from rights that otherwise are accorded to "everyone". In addition, there are several problematic aspects of statistics related to its individualizing and codified function: people who empirically have little in common except that they are living without legal authorization in a nation-state become part and representatives of a category, which in turn becomes the basis for political control (de Genova 2002). Such individualization and categorization obscures the heterogeneous category in terms of national origin, sex, age, ethnicity and religion.

It is primarily from a management perspective that migrants are classified into subcategories as asylum seekers, migrant workers, refugees, family reunification or unaccompanied minors. It is part of an effort to control and normalize what empirically is a very complex migration flow (Feldman 2011). The categories and taxonomies constructed by the

3 New figures from a 2014 report estimate that there are between 18,100 and 56,000 people "without legal residence" in the country. 
state and the media have a management perspective or a state-centric focus that reinforces the concept of crossing borders in a "legitimate" or illegitimate way (Soguk 2007). Such border-related categories and definitions of migrants are implemented as part of a sovereign right-claim of the nation-state to decide who its citizens are (Noiriel 2001). The effect of such categorization is that migrants are objectified (Feldman 2011). While the Norwegian authorities use the term "persons without legal residence", the research literature and public debate make use of different categories for the same or partially overlapping categories of people, including "undocumented", "paperless" or "sans papier", "illegal”, "non-status migrants", "unreturnable" or "return deniers". The battle over the terms also indicates how migration control and inclusion in the nation-state is both a legal and moral concern. Nyers (2010: 135) argues that " $\mathrm{t}]$ he charge of illegality is meant to undermine the moral character of certain types of migrants [...] The term 'illegal' implies a breaking of the legal order, a violation of rule-following norms of behaviours, and an intention to commit a wrong." In the public debate the issue of irregulars' rights to residence and welfare move from well-integrated irregular migrants who are presented as contributing to society, to dope dealers. Frequently, the media draws on emotional argumentation which centres around those who are "less fortunate" and who "deserve our sympathy" on the one hand, and those whose actions define them as "undeserving" and "illegitimate" and should thus be forcefully returned.

The main argument against using the term "illegal immigrant" is that a person cannot be illegal, only the actions of a person can contravene existing laws (Nyers 2010). In my research I have chosen to speak of "irregular migration", because this is quite broad and can include political, social and economic mechanisms in addition to the legal dimension (see Thomson 2010). By using "irregular" or "irregularized" the starting point becomes examining how individuals and groups are "irregularized" in the interaction between specific migration flows and the legal, political, social and economic mechanisms. The term suggests how a person's administrative status may change as a result of changes in laws and regulations. A person's legal status depends on a number of factors related to national legislation and its interpretation, the development of the country they migrated from and its international relations with Norway, as well as individuals' changing status (for example relating to marriage, childbirth, illness, etc.) (cf. Thomsen 2010).

Furthermore, the illegal/legal dichotomy is not as clear-cut as it might seem. In France, Chauvin and Graces-Macarena (2012) argues that "illegality" increasingly seems to operate as a continuum, where migrants may accumulate official and semi-official documents and certificates of attendance and participation in society, in hopes of making themselves less subject to deportation or to make legalization possible in the future. This is perhaps less the case in Norway compared to France, where some groups are provided access to regularization by documenting their number of years of residence in the country (ibid.). From the migrants' perspective, in my fieldwork I realized that the border between being legal and illegal is experienced as unclear because of the complexity of the system of migration control. The experiences of being irregular, however, are not only related to the legal status as an irregular (Bendixsen 2015). The situation of a rejected asylum seeker changes radically if a return agreement with the country of his/her nationality is implemented. A return agreement facilitates the deportation and forced return of irregular migrants, turning irregular migrants into deportable subjects. 


\section{DEPORTABILITY - PRODUCING DEPORTABLE SUBJECTS}

In the last decade there has been an increase in the use of deportation, detention, deterrence and return as a way of dealing with the irregular population in Europe and the United States. This intensification of control has been called "deportation regimes" (Genova, Peutz 2012), referring to how these policies and practices produce deportable human beings and describe a "deportation turn" in how Western nation-states deal with unwanted non-citizens (Anderson, Gibney, Paoletti 2011). Deportation is defined as "the compulsory removal of "aliens" from the physical, juridical, and social space of the state" (De Genova, Peutz 2010: 1).

The practice of deportation, I argue, is closely linked to programs of assisted return developed by several European countries. The Norwegian government has an explicit policy objective to encourage irregular migrants to leave "voluntarily". This is done through introducing asylum seekers to the program of assisted return which is organised by IOM (International Organisation of Migrants) on behalf of the Norwegian authorities. As part of this objective to encourage assisted return, the Norwegian government continues to implement agreements with relevant countries facilitating the return of irregular migrants by force (Bendixsen, Lidén 2016), also called deportation. Such agreements that legalise forced return or deportation simultaneously increase deportability. It also testifies to how deportability is characterised by relatively high levels of cooperation at the international scale. Additionally, as in the EU countries, Norwegian authorities operate with "targets" for deportation. In the last couple of years these have increased: from 3,700 in the consolidated budget in 2010 to 4,600 in 2011, 5,298-7,100 in 2014 (the police (PU) transported 7,259 in 2014), and 7,800 in 2015 (7,825 were reported to have been transported in 2015). ${ }^{4}$ While the number of deportations has been rather stable for the last 2-3 years, in 2016 the media argued that the government "needs" to forcefully return 16,000 people, although there is a lack of capacity to pursue this. Walters (2002: 280) suggests that

When deportation rates become "targets" to be met by immigration and other departments, when national and international agencies seek to compare levels and techniques of deportation across nations and exchange information for "best practices", then it seems we have governmentalization of government.

Targeting irregular migrants to be deported within a particular budget year is described by the authorities as a necessary means for maintaining a fair asylum process, and is also meant to discourage other (potential) migrants from coming to Norway, sending a message with the deported people that they will not receive asylum or be allowed to stay "illegally" in Norway. As the Minister of Immigration and Integration Sylvi Listhaug of the right-wing Progress Party said in the parliament on the day after her appointment: "[p] ursuing active return work will limit the arrival of more unjustified asylum seekers". ${ }^{5}$ She added: "I will also make sure that those who do not have the right to stay are sent out as quickly as possible."

4

5
Figures from https://www.politi.no/politiets_utlendingsenhet/statistikk/ (25. 6. 2016).

http://www.aftenposten.no/norge/Inntil-16000-skal-tvangsreturneres-i-ar_-men-Norge-harbare-kapasitet-til-a-sende-ut-halvparten-16152b.html (22. 6. 2016). 
"Active return work" is thus linked to deterrence policies and forced return. Part of such deterrence policies includes the emergence of specialized detention facilities that expedite deportation, and various public campaigns, such as ads on trains, subway stations and on taxis in Oslo to apply for assisted return. Such practices are central to the production of perceptions of "irregular migrants". Public justifications of forced return include presenting these people as economic migrants without legitimate asylum claims - even if many of them claim otherwise.

The increase in deportation or immigration enforcement has by scholars been attributed to increased anxiety associated with the war on terror, the prison-industrial-detention-centre complex's need to justify its existence, racialisation, scapegoating, and the labour needs of capitalism in the neoliberal era (de Genova 2002; de Genova, Peutz 2010; Coutin 2015). In the USA, de Genova (2002) argues that because it was nearly unfeasible, both physically and politically, to deport the around 12 million irregular immigrants living in the country, deportation policies are not about reaching this goal. Instead, he suggests, deportation produces deportability and thus increases irregular migrants' awareness that they risk deportation, which may decrease their capacity to oppose or question exploitative labour conditions in the neo-liberal global economy. Similarly, Khosravi (2010) describes how 'illegal' migrants in Sweden felt constantly monitored, and how they in consequence became obedient, disciplined individuals. Fear of deportation or being produced as a deportable subject "produces and maintains migrant 'illegality' as not merely an anomalous juridical status but as a practical, materially consequential, and deeply interiorized mode of being - and of being put in place" (Peutz, de Genova 2010: 14). As a consequence of such socio-political exclusion, irregular migrants have become the "modern proletarians" (Balibar 2000: 42).

In Norway, research has so far not suggested that irregular migrants represent an important labour force. Deportation in Norway is currently instead linked to an effort to increase motivation among irregular migrants to sign up for assisted return (Bendixsen, Lidén 2016), and thus it is part of an effort to reduce asylum pressures. But the effects of being deportable on irregular migrants' living conditions are similar. Living as an irregular migrant involves living with the awareness that he or she can be deported, which affects everyday life (Willen 2007; Khosravi 2010; Kjærre 2010; Bendixsen 2015). During my fieldwork, I observed that some migrants try to make themselves invisible to the authorities by trying to dress and move in ways or places that makes them unnoticeable, or by avoiding seeking health care when they felt ill because they feared that authorities would be notified (Bendixsen 2015). It also involved taking extra precautions of not committing minor acts of breaking the law, such as always paying for their bus tickets. I also interviewed several migrants who worked on the informal market for very low pay (as low as 1 Euro an hour), and other times never receiving the promised money. They had nowhere to turn to complain, and continued working informally as precarious workers, hoping not to be tricked the next time around.

One last feature of deportability needs mentioning. Deportability is consequential not only for aliens but also for people with permanent residence, and this is tied to the maximum sentence set out in the penal provision. In Norway, the expulsion rules say that "a foreign national who was granted a permanent residence permit before the criminal offence was committed can be expelled if the offence (under Norwegian law) can lead 
to imprisonment for a term of two years or more". ${ }^{6}$ Thus, governing through deportation means that rather than being dichotomous categories, the citizen and the alien become situated on an interconnected continuum defined by moral, economic, and cultural "borderscapes" (Mezzadra, Neilson 2013). It calls attention to the fact that making clear-cut distinctions between 'open' or 'closed' borders, and between 'citizens' or 'aliens', is misleading (Jansen 2015). It also demonstrates how criminal law and migration law have become increasingly connected, to which I now finally turn.

\section{THE CRIMINALIZATION OF IRREGULAR MIGRANTS}

Two previously separate spheres of state control - immigration control and crime control - have increasingly begun to overlap, seeping into each other and setting the terms for each other in a new formation that researchers call "crime migration" (Johansen, Ugelvik, Aas 2013).

In Norway, Aas (2014: 525) has asserted that "[c]riminal law is applied not only to punish, but also to deport, while deportation is used not only for immigration purposes, but also because an individual is seen as a law and order problem (without necessarily needing to prove so with criminal law procedural means)." The merging of these two spheres (crime and migration) emphasizes the centrality of citizenship or legal residency to the domestic penal order (Bosworth, Guild 2008; Aas 2014), as well as to the global mobility regime (Aas 2014). The increasingly strong connection constructed between border security, boundary management, migration and crime in post-cold war Norway can be illustrated by the exponential growth in deportations based on criminal sentencing: from 190 decisions in 1991, the number of migrants deported from Norway on the basis of having been convicted of a crime increased exponentially to nearly 2,500 decisions in 2014 (Aas, Mohn 2015).

Detention of migrants is usually considered to be different from incarceration, as it is pursued more for "administrative" purposes rather than as detention of a person who committed or allegedly committed a crime (Sampson, Mitchell 2013). Detention is viewed as an 'effective migration management' tool and a governmental practice used for deprivation of liberty in the absence of a criminal charge (ibid.). While in some countries, entering the country without proper authorization is an administrative offence, and not a crime, in Norway it can carry a prison sentence. A few years ago, unauthorized stay could be punished with 30 days in prison, in 2013 it was increased to 60 days, and in 2014 to one year. In 2015, politicians from the Progress Party argued that it should be illegal to provide healthcare to irregular migrants, it should be a duty of healthcare workers to report if they provide assistance to irregular migrants, and that it should be punishable to rent apartments irregular migrants. The motion was dismissed, but such public shaming of irregular migrants amplifies uncertainty around how citizens should respond to irregular migrants and adds to the discursive criminalization of migrants.

A similar intertwining of immigration issues and criminality is also found in the media. The media is important for our understanding of who is worthy of sacrificing, and who are morally legitimate suffering individuals. The questions of deportation and irregular access to welfare services have received attention in the Norwegian media, which mainly

http://www.une.no/en/Cases/Expulsion-rules/ (24. 6. 2016). 
constructs irregular migrants either as worthy of being included or as a threat to society. The media has focused on crime in relation to persons without legal residence, and has criticized the government for allowing "criminal asylum seekers" to be in the country and enjoy welfare benefits. On the other hand, the media has also criticized the government for carrying out inhumane asylum policies, and for deporting Norwegians and refusing people humanitarian aid. Constructing an idea of migrants as "productive" or "harmless" vs. "unproductive" or "problematic", such policy responses have fed into the increasingly strict social environment for refugees and asylum seekers in recent years. ${ }^{7}$ Crimes conducted by migrants are frequently viewed as a sign of their "foreignness", thus constructing them as "Other" and deviant (Aas 2013). These representations of irregulars are also gendered. While women and children are often portrayed as innocent victims, men are more often associated with crime and danger.

\section{CONCLUSION}

The governmentality of irregular migrants is simultaneously the production of such a category of people. Irregular migrants are constructed as particular subjects not only through laws regulating entry and exit of the nation-state and the Schengen external border zone, but also through the internal national welfare-state's laws and regulations and their interpretations as practiced by governmental agencies. The escalation of border management and border production at various scales multiply social borders, for example through welfare regulations and the enforcement thereof by welfare state gatekeepers. This means that irregular migrants are produced as a category in multiple ways and at various scales.

Facilitating deportation through third-country agreements and partly legitimizing such practices through the implementation of assisted return programmes that are presented as viable alternatives simultaneously produce deportable subjects. This governing practice calls attention to the continuum between aliens and citizens. Finally, the process of criminalizing migrants, constructing images of the dangerous or deviant migrant, is part of the symbolic control of national territory, although with real consequences for the people in question.

Research on irregular migrants and their legal, institutional and empirical exclusion from and inclusion in welfare schemes are both methodologically and ethically challenging. In light of this, as researchers it becomes imperative to reflect upon the categories we as researchers use, as well as our analytical focus and knowledge production, because it ultimately may have an impact on how people defined as irregular migrants are viewed, recognized and treated.

7 Paradoxically, "criminalized" people are not necessarily losing access to welfare rights. The status of criminal and subsequent inclusion in the judicial system and the status of prisoner may provide better protection and effective access to welfare than the status of "irregular migrant". For instance, an irregular migrant in prison will, in theory, have the same access to health care as all other inmates. Hannah Arendt (2004) [1948] alluded to this paradox in her discussion of refugees and the stateless in Europe in The Origins of Totalitarianism, where she argues that the best criterion by which to decide if someone has been forced outside the law is whether someone's legal position would be improved by committing a crime. 


\section{REFERENCES}

Aas Franko, Katja (2013). Globalization \& Crime. Sage: London.

Aas Franko, Katja (2014). Bordered penality: Precarious membership and abnormal justice. Punishment \& Society 16/5, 520-541.

Aas Franko, Katja, Book Mohn, Sigmund (2015). Utvisning som straff? Om grensesnittet mellom strafferett og utlendingskontroll. Tidsskrift for Strafferett TFS 2015-2.

Andersen, Jørgen G., Bjørklund, Tor (1990). Structural changes and new cleavages: The progress parties in Denmark and Norway. Acta Sociologica 33/3, 195-217.

Anderson, Bridget, Gibney, Matthew J., Paoletti, Emanuela (2011). Citizenship, Deportation and the Boundaries of Belonging. Citizenship Studies 15/5, 547-563.

Arendt, Hannah (2004) [1948]. The Origins of Totalitarianism. New York: Schocken Books.

Balibar, Etienne (2000). What We Owe to the San-Papier. Social Insecurity (eds. Guenther Len, Cornelius Heesters). Toronto: Anansi, 42-44.

Balibar, Etienne (2002). Politics and the other scene. London: Verso.

Bendixsen, Synnøve (2013). Becoming Members in the Community of Value: Ethiopian Irregular Migrants Enacting Citizenship in Norway. Migration Matters (eds. Dugan Mahni, Arnon Edelstein). Oxfordshire: Inter-Disciplinary Press, 3-22.

Bendixsen, Synnøve (2015). Vilkårlige rettigheter? Irregulære migranters tillit, sosiale kapital og kreative taktikker. Eksepsjonell velferd? Irreguloere migranter $i$ det norske velferdssamfunnet (eds. Synnøve Bendixsen, Christine M. Jacobsen, Karl-Harald Søvig). Oslo: Gyldendal, 184-202.

Bendixsen, Synnøve (2016). The Refugee Crisis; Destabilizing and Restabilizing European Borders. History and Anthropology 1-19, DOI: 10.1080/02757206.2016.1221407.

Bendixsen, Synnøve, Lidén, Hilde (2016). Return to well-being? Irregular migrants and assisted return in Norway. Return migration and psychosocial wellbeing (eds. King Russel, Zanna Vathi). London: Routledge.

Bosworth, Mary, Guild, Mhairi (2008). Governing through migration control: Security and citizenship in Britain. British Journal of Criminology 48/6, 703-719.

Chauvin, Sébastien, Graés-Macarena, Blanca (2012). Beyond Informal Citizenship: The New Moral Economy of Migrant Illegality. International Political Sociology 6/3, 241259.

Coutin Bibler, Susan (2015). Deportation Studies: Origins, Themes and Directions. Journal of Ethnic and Migration Studies 41/4, 671-681.

Dean, Mitchell (2010). Governmentality: Power and Rule in Modern Society, 2. ed. Thousand Oaks, CA: SAGE Publications.

De Genova, Nicholas (2002). Migrant "Illegality" and Deportability in Everyday Life. Annual Review of Anthropology 31, 419-447.

De Genova, Nicholas (2005). Working the Boundaries: Race, Space and "Illegality" in Mexican Chicago. Durham: Duke University Press.

De Genova, Nicholas (2010). The deportation regime: Sovereignty, space and the freedom of movement. The deportation regime: Sovereignty, space and freedom of movement (eds. Nicholas De Genova, Nathalie Peutz). Durham, NC: Duke University Press, 33-65.

De Genova, Nicholas, Peutz, Nathalie (eds.) (2012). The deportation regime: Sovereignty, space and freedom of movement. Durham, NC: Duke University Press, 33-65. 
Esping Andersen, Gøsta (1990). The three Worlds of Welfare Capitalism. Cambridge: Polity Press.

Fassin, Didier (2011). Policing Borders, Producing Boundaries: The Governmentality of Immigration in Dark Times. Annual Review of Anthropology 40, 213-226.

Feldman, Gregory (2011). The Migration Apparatus: Security, Labor, and Policymaking in the European Union. Palo Alto: Stanford University Press.

Foucault, Michel (1991). Governmentality. The Foucault Effect: Studies in Governmentality (eds. Graham Burchell, Colin Gordon, Peter Miller). Chicago: University of Chicago Press, 87-104.

Foucault, Michel (2002). The Archeaology of Knowledge. London: Routledge.

Guiraudon, Virginie, Lahav, Gallia (2000). A reappraisal of the state sovereignty debate the case of migration control. Comparative Political Studies 33/2, 163-195.

Jansen, Yolande (2015). Deportability and Racial Europeanization: The Impact of Holocaust Memory and Postcoloniality on the Unfreedom of Movement in and to Europe. The Irregularization of migration in contemporary Europe: Detention, deportation, drowning (eds. Yolande Jansen, Robin Celikates, Joost de Bloois). London: Rowman \& Littlefield, 15-30.

Johansen, Nicolay B., Uglevik, Thomas, Franko Aas, Katja (2013). Krimmigrasjon: Den nye kontrollen av de fremmede. Oslo: Universitetsforlaget.

Khosravi, Shahram (2010). 'Illegal' Traveller: An Auto-Ethnography of Borders. London: Palgrave Macmillan.

Kjærre, Halvar A. (2010). No direction home - The margins of a welfare state and the illegalised body. Irregular migration in a Scandinavian perspective (eds. Trine Lund Thomsen, Martin Bak Jorgensen, Susi Meret, Kirsten Hviid, Helle Stenum). Maastricht: Shaker Publishers, 231-257.

Mezzadra, Sandro, Neilson, Bret (2013). Border as Method or, the Multiplication of Labor. Durham: Duke University Press.

Noiriel, Gerard (1991). État, nation et immigration: Vers une histoire du pouvoir. Pariz: Gallimard.

Nyer, Peter (2010). No one is Illegal between City and Nation. Studies in Social Justice 4/2, 127-143.

Olwig, Karen F. (2010). Integration: Migrants and Refugees between Scandinavian Welfare Societies and Family Relations. Journal of Ethnic and Migration Studies 37/2, 179-196.

Reeves, Madeleine (2014). Border Work: Spatial Lives of the State in Rural Central Asia. Ithaca: Cornell University Press.

Rugkåsa, Marianne (2012). Likhetens dilemma: Om sivilisering og integrasjon I den velferdsambisiøse norske stat. Oslo: Gyldendal Akademisk.

Rumford, Chris (2011). Citizens and Borderwork in Contemporary Europe. London: Routledge.

Sampson, Robyn, Grant, Mitchell (2013). Global trends in immigration detention and alternatives to detention: Practical, political and symbolic rationales. Journal on Migration and Human Security 1/3, 97-121.

Sassen, Saskia (1996). Losing control? New York: Columbia University Press.

Sassen Saskia (1998). Globalization and Its Discontents: Essays on the New Mobility of People and Money. New York: New Press. 
Sigona, Nando, Hughes, Vanessa (2012). No way out, no way in: Irregular migrant children and families in the UK. COMPAS-rapport. Oxford: University of Oxford.

Soguk, Nevzat (2007). States and Strangers: Refugees and Displacements of Statecraft. University of Minneapolis, Minnesota Press.

Søvig, Karl Harald (2013). Hvorfor nekte, eller gi, irregulære migranter tilgang til velferdsytelser? Undring og erkjennelse (eds. Ørnulf Rasumssen, Sigrid Eskeland Schütz, Karl Harald Søvig). Bergen: Fagbokforlaget, 705-717.

Soysal, Yasemin (1994). Limits of citizenship. Chicago: Chicago University Press.

Spencer, Sarah (2003). Introduction: The Politics of Migration, Managing Opportunity, Conflict and Change (ed. Sarah Spencer). The Political Quarterly, Special Issue.

Thomsen Lund, Trine (2010). Irregular Migration in a Scandinavian Perspective. Irregular Migration in a Scandinavian Perspective (eds. Trine Lund Thomsen, Martin Bak Jørgensen, Susi Meret, Kirsten Hviid, Helle Stenum). Maastricht: Shaker Publisher, 27-47.

Walters, William (2002). Deportation, Expulsion, and the International Police of Aliens. Citizenship Studies 6/3, 265-292.

Walters, William (2012). Governmentality: Critical Encounters. Routledge: London.

Willen, Sarah (2007). Toward a Critical Phenomenology of "Illegality": State Power, Criminalization and Abjectivity among Undocumented Migrant Workers in Tel Aviv, Israel. International Migration 45/3, 8-38.

Yuval Davis, Nira (2004). Borders, boundaries and the politics of belonging. Ethnicity, Nationalism and Minority Rights (eds. Stephen May, Tariq Modood, Judith Squires). Cambridge: Cambridge University Press, 214-230.

Zhang, Li-Chun (2008). Developing methods for determining the number of unauthorized foreigners in. Norway. 2008/11. Statistics Norway/Division for Statistical Methods and Standards. 


\section{POVZETEK}

\section{USTVARJANJE NEDOKUMENTIRANIH MIGRANTOV: PRIMER NORVEŠKE Synnøve BENDIXSEN}

Nedokumentirane migracije so v porastu tako v Evropi kot drugje po svetu. Na Norveškem, kot tudi v preostalih evropskih državah, zaznavajo zastoj liberalizacije azilnih in migracijskih politik in porast restriktivnih ukrepov. Članek temelji na raziskavi o nedokumentiranih migracijah in avtoričinem terenskem delu z nedokumentiranimi migranti na Norveškem ter podaja analizo štirih področij vladnih ukrepov, ki pojasnjujejo način ustvarjanja nedokumentaranosti. Prvič, nedokumentirani migranti so kot taki konstruirani skozi prizmo zakonov, ki regulirajo vstop in izstop iz nacionalne države in zunanjih meja šengenskega območja, in (interpretacij) v državah blaginje veljavnih zakonov. Del notranjih oz. socialnih meja na Norveškem so namreč tudi regulativni predpisi o upravičenosti do določenih pravic, dostopa do zdravstvene oskrbe, zatočišča in hrane. Eskalacija upravljanja in vzpostavljanja meja na različnih ravneh dostopa do ugodnosti, ki jih nudi država blaginje, povzroča nastanek številnih socialnih/družbenih razmejevanj.

Drugič, število in konstrukcija kategorij nedokumentiranih migrantov sta pomemben del razumevanja nedokumentiranosti: nekateri ga razumejo v kontekstu humanitarnosti, drugi v kontekstu varnosti. Za moderne oblike vladavine so statistike ključnega pomena (Foucault 2002). V primeru nedokumentiranih migracij se s statistiko identificirajo tisti, ki so v državi neupravičeno in jim je zato treba onemogočiti dostop do »univerzalnih" socialnih pravic. Umeščanje različnih ljudi, ki jim je skupno le to, da v državi prebivajo brez legalnega statusa, v eno skupino, zanemarja heterogenost narodnosti, spola, starosti, etnične pripadnosti in religije.

Tretjič, deportacije, ki so v okviru sporazumov s tretjimi državami legitimizirane v programih pomoči pri vračanju in predstavljene kot sprejemljive alternative za nedokumentirane migrante, hkrati ustvarjajo kategorijo subjektov za deportacijo. Tovrstna oblika vladanja pozornost usmerja na kontinuum med državljani in tujci. In četrtič, proces kriminalizacije migrantov je del simbolnega nadzora nad nacionalnim teritorijem in konstruira podobe nevarnih in deviantnih migrantov.

Namen kompleksno prepletenih vladnih tehnik je upravljati z ljudmi, ki so v državi "nezakonito«. Članek se osredotoča na načine konfiguracije in ustvarjanja nedokumentiranih migrantov na ozemlju nacionalne države, saj prav vladnost nedokumentiranih migracij hkrati ustvarja tovrstno kategorizacijo ljudi. Raziskovalci morajo pri ustvarjanju novega znanja kategorije premišljeno uporabljati, saj lahko te močno vplivajo na dojemanje nedokumentiranih migrantov in odnos do njih. 